\title{
Rancang Bangun Aplikasi Dengan Linear Congruent Method (LCM) Sebagai Pengacakan Soal
}

\author{
Muhammad Ganda Arizqia ${ }^{1}$, Anang Aris Widodo ${ }^{2}$
}

\begin{abstract}
Education is an important thing that should be owned by everyone. The quality of education can be seen through the test execution to determine the achievement of success in understanding the capabilities and fields of study taken. Along with the development of information technology and communications test systems are no longer using the conventional media but has been computerized. conventional test execution prone to leaks about to be filed before the test and fraud such as cheating friend answers.

Because of the weakness that needs to be done about the randomization design. Randomization of the questions are designed and implemented using the Linear Congruent Method (LCM). Randomization this matter is expected to overcome the weaknesses of the existing way so that each party can make its own problems effectively and efficiently.
\end{abstract}

Intisari- Pendidikan merupakan hal penting yang harus dimiliki oleh setiap orang. Kualitas pendidikan dapat diketahui dengan melalui pelaksanaan ujian untuk mengetahui pencapaian kemampuan dan keberhasilan dalam memahami bidang studi yang ditempuhnya. Seiring perkembangan teknologi informasi dan komunikasi sistem ujian sudah tidak lagi menggunakan media konvensional melainkan sudah secara komputerisasi. pelaksanaan ujian secara konvensional rentan terhadap kebocoran soal yang akan diajukan sebelum ujian dan kecurangan yang dilakukan seperti mencontek jawaban teman.

Adanya kelemahan itulah perlu dilakukan perancangan pengacakan soal. Pengacakan soal tersebut dirancang dan diimplementasikan dengan menggunakan metode Linear Congruent Method (LCM). Pengacakan soal ini diharapkan mampu mengatasi kelemahan dari cara yang ada sehingga setiap pihak dapat membuat soal nya sendiri secara efektif dan efisien.

Kata Kunci- Pengacakan Soal, Linear Congruent Method, Perancangan

\footnotetext{
${ }^{1}$ Mahasiswa, Jurusan Teknik Informatika Fakultas Teknologi Informasi Universitas Merdeka Pasuruan, Jalan Ir. H. Juanda No 68 Pasuruan INDONESIA (e-mail: masmus.sanqta@gmail.com) 2, Dosen, Jurusan Teknik Informatika Fakultas Teknologi Informasi Universitas Merdeka Pasuruan, Jalan Ir. H. Juanda No 68 Pasuruan INDONESIA (e-mail: anangariswidodo@gmail.com )
}

\section{PENDAhuluaN}

\section{A. Latar Belakang}

Pendidikan merupakan hal penting yang harus dimiliki oleh setiap orang. Kualitas pendidikan dapat diketahui dengan melalui pelaksanaan ujian untuk mengetahui pencapaian kemampuan dan keberhasilan dalam memahami bidang studi yang ditempuhnya.

Pelaksanaan ujian secara konvensional maupun komputerisasi perlu memperhatikan terhadap tindak kecurangan yang mungkin saja terjadi. Hal tersebut dipicu karena kepercayaan diri peserta menurun ketika mengerjakan soal ujian sehingga lebih percaya kepada peserta lain. Selain itu pemberian tipe soal ujian yang sama akan memberikan peserta berpeluang untuk mencontek dan bekerja sama.

Penelitian ini bertujuan untuk memberikan solusi berupa penerapan tipe soal yang berbeda-beda sehingga dapat meminimalkan tindak kecurangan yang mungkin dilakukan oleh peserta ujian. Penerapan pengacakan soal pada aplikasi ujian yang dibuat menggunakan metode Linear Congruential Method (LCM). Penentuan konstanta pada Linear Congruential Method (LCM) sangat menentukan baik tidaknya bilangan acak yang diperoleh dalam arti memperoleh bilangan acak yang seakan - akan tidak terjadi pengulangan.

Berdasarkan uraian di atas akan dibuat sebuah rancang bangun aplikasi ujian dengan Linear Congruent Method (LCM) sebagai metode pengacakan soal yang merupakan suatu perangkat lunak untuk membantu membuat soal agar berjalan efektif.

\section{METODE PENELITIAN}

A. Analisa

Setelah perencanaan selesai, langkah berikutnya adalah membuat analisa (analyst). Pada tahapan ini dilakukan analisis terhadap sistem dan prosedur yang biasa dilakukan dan penentuan fungsi-fungsi pelayanan.

1. Analisa Kebutuhan Perangkat Lunak

Perangkat lunak memiliki peranan penting dalam mengembangkan sistem terutama untuk implementasi kode program. Perangkat lunak yang digunakan untuk membangun aplikasi ini adalah sebagai berikut :

- Sistem Operasi Windows XP/7/8/8.1/10

- Microsoft Office Sharepoint Designer

- XAMPP

2. Analisa Kebutuhan Perangkat Keras

- Prosesor Intel Core 2Duo 2,4 Ghz

- Memory $2 \mathrm{~Gb}$

- Minimal spasi harddisk (kosong) $25 \mathrm{~GB}$ 


\section{B. Desain}

Setelah proses analisa selesai, selanjutnya adalah membuat desain . Adapun macam - macam desain sebagai berikut:

1. UML (Unified Modeling Language) adalah adalah suatu bagan dengan simbol-simbol tertentu yang menggambarkan urutan proses secara mendetail dan hubungan antara suatu proses (instruksi) dengan proses lainnya dalam suatu program.

\section{a. Activity Diagram}

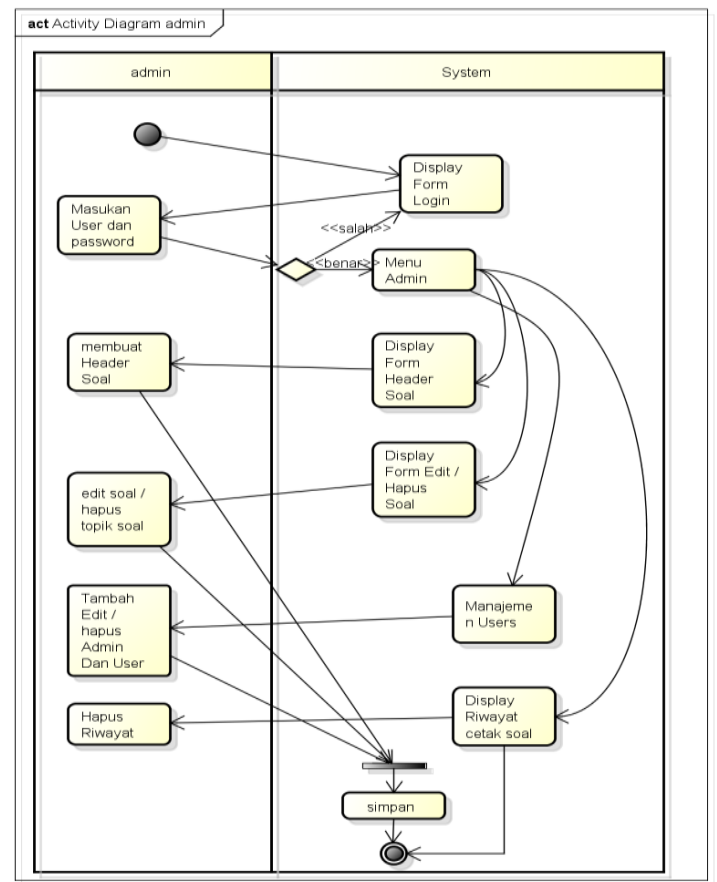

Gambar 1. Activity Diagram Admin

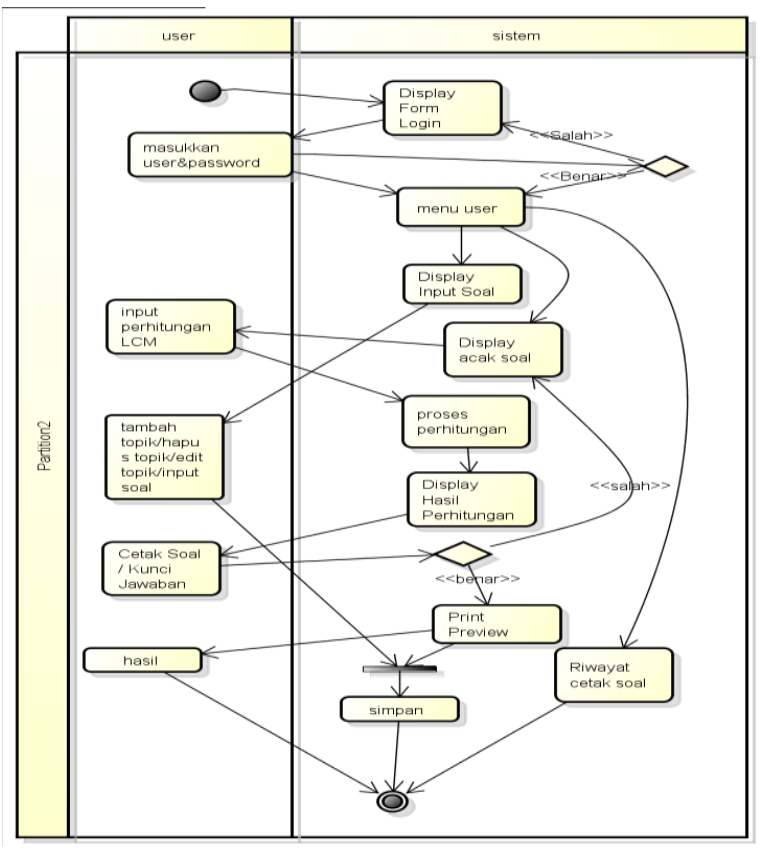

Gambar 2. Activity Diagram User b. Sequence Diagram

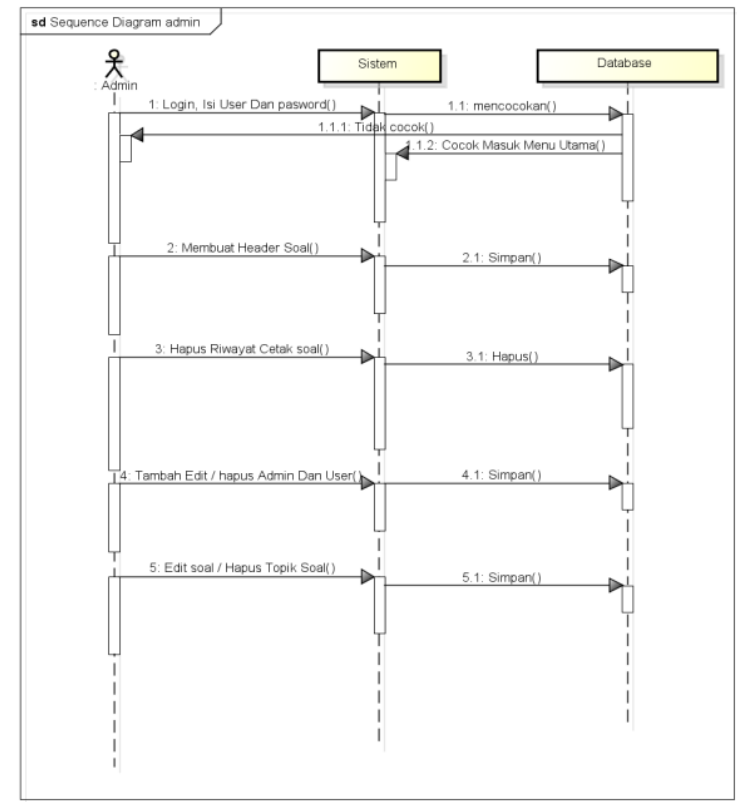

Gambar 3. Sequence Diagram Admin

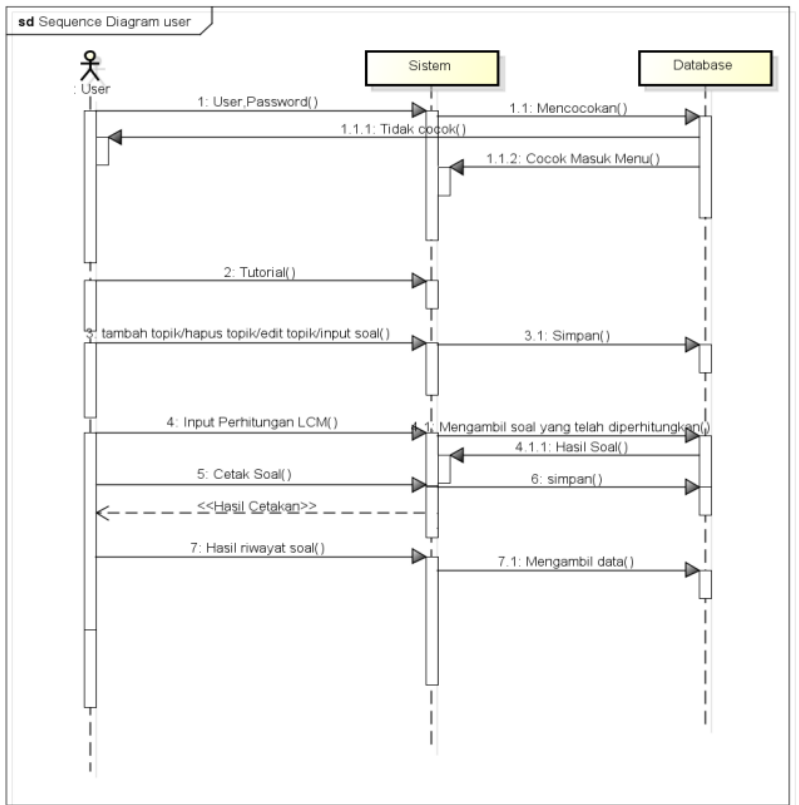

Gambar 4. Sequence Diagram User

2. ERD (Entity Relationship Diagram) adalah suatu model untuk menjelaskan hubungan antar data dalam basis data berdasarkan objek-objek dasar data yang mempunyai hubungan antar relasi. 


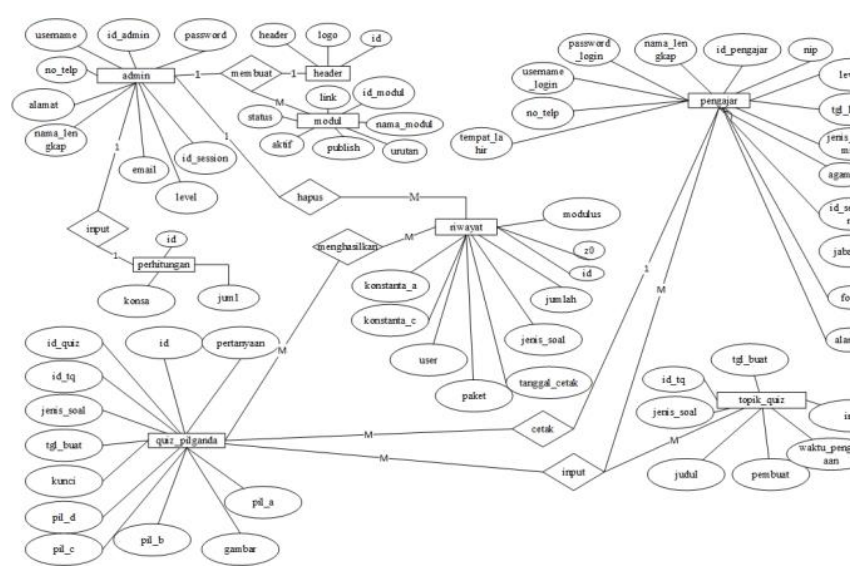

Gambar 5. Entity Relationship Diagram

\section{Desain Input}

Tahapan berikutnya adalah melakukan perancangan desain input atau desain form. Adapun beberapa desain input yang dirancang untuk aplikasi ini diantaranya :

1. Halaman Login

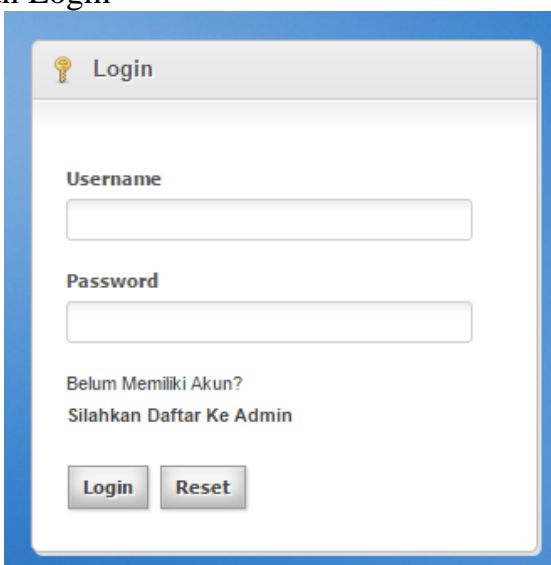

Gambar 6. Form Login

Halaman ini adalah halaman awal saat membuka aplikasi pertama kali. Berfungsi sebagai pembeda antara user dan admin.

2. Halaman Header Soal

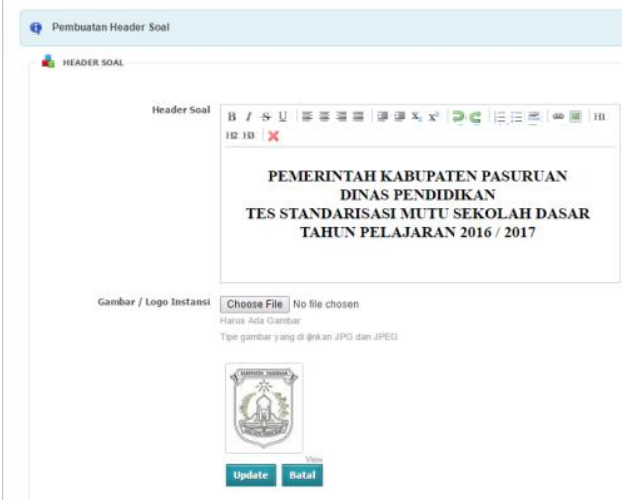

Gambar 7. Halaman Header Soal

Halaman ini berfungsi untuk mengelola header soal yang di inginkan pada header soal.
3. Halaman Tambah Topik

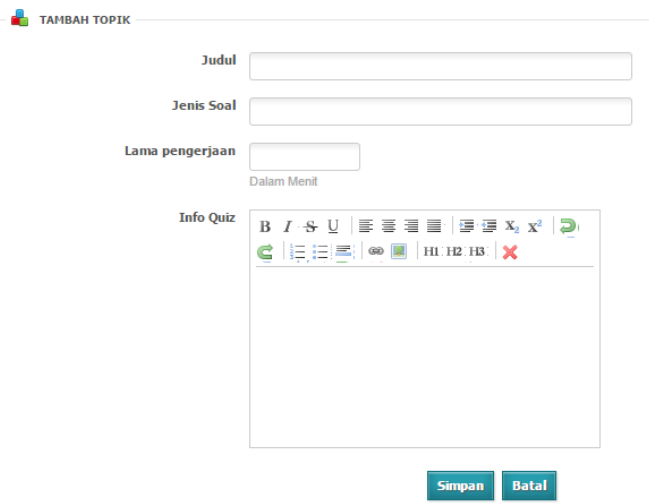

Gambar 8. Halaman Tambah Topik

Halaman ini berfungsi untuk menambah suatu topik soal yang akan di inputkan.

4. Halaman Input Soal

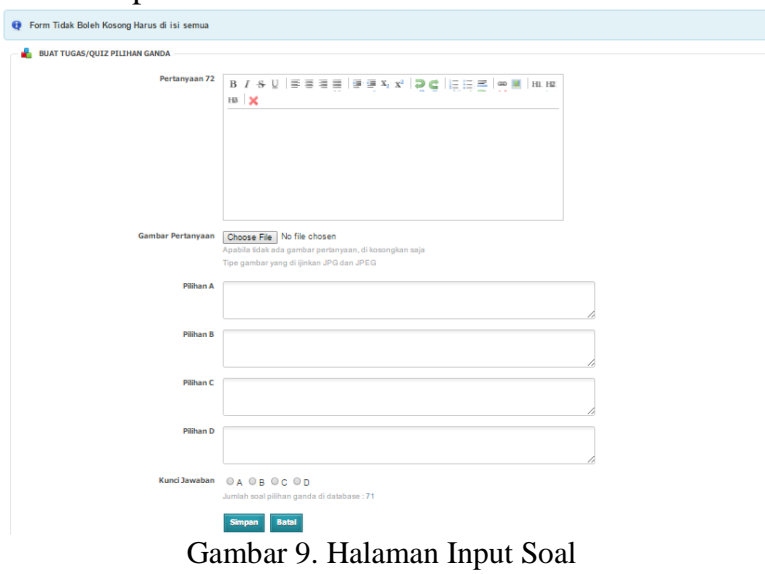

Halaman ini berfungsi untuk menginputkan soal yang nantinya akan tersimpan di database beserta kunci jawabannya.

D. Linear Congruent Method (LCM)

Linear Cogruent Method (LCM) merupakan pembangkit bilangan acak yang banyak digunakan dalam program komputer.

LCM membangkitkan bilangan acak yang didefinisikan dengan:

1) $Z_{i}=\left(a Z_{i-1}+c\right) \bmod m(1)$

Dimana :

$\begin{array}{ll}\mathrm{Zi} & =\text { bilangan acak } \mathrm{ke}-\mathrm{i} \\ \mathrm{Zi}-1 & =\text { bilangan acak sebelum nya } \\ \mathrm{a} & =\text { faktor pengali } \\ \mathrm{c} & =\text { increment } \\ \mathrm{m} & =\text { modulus }\end{array}$

Menurut Thomas J. Kikay dalam bukunya Pengantar Sistem Simulasi menyebutkan bahwa syarat-syarat untuk menentukan konstanta dalam $L C M$ adalah sebagai berikut :

1. Konstanta $a$ harus lebih besar dari $\sqrt{m}$ 
2. Untuk konstanta $c$ harus berangka ganjil apabila $m$ bernilai pangkat dua. Tidak boleh nilai dari kelipatan $m$

3. Untuk $m$ harus bilangan prima

4. Untuk pertama $z O$ harus merupakan angka integer dan juga ganjil cukup besar.

ini :

Dapat Dilihat dari beberapa contoh seperti dibawah

Rumus :

$Z_{i}=\left(a Z_{i-1}+c\right) \bmod m$

$\mathrm{a}=11$

$\mathrm{c}=5$

$\mathrm{z} 0=1$

$\mathrm{m}=23$

Penyeleseian :

$\mathrm{Z}(1)=(11 * 1+5) \bmod 23=16$

$Z(2)=(11 * 16+5) \bmod 23=20$

$Z(3)=(11 * 20+5) \bmod 23=18$

$Z(4)=(11 * 18+5) \bmod 23=19$

$Z(5)=(11 * 19+5) \bmod 23=7$

$Z(6)=(11 * 7+5) \bmod 23=13$

$Z(7)=(11 * 13+5) \bmod 23=10$

$Z(8)=(11 * 10+5) \bmod 23=0$

$Z(9)=(11 * 0+5) \bmod 23=5$

$\mathrm{Z}(10)=(11 * 5+5) \bmod 23=14$

$\mathrm{Z}(10)=(11 * 14+5) \bmod 23=21$

$Z(12)=(11 * 21+5) \bmod 23=6$

$\mathrm{Z}(13)=(11 * 6+5) \bmod 23=2$

$Z(14)=(11 * 2+5) \bmod 23=4$

$Z(15)=(11 * 4+5) \bmod 23=3$

$Z(16)=(11 * 3+5) \bmod 23=15$

$\mathrm{Z}(17)=(11 * 15+5) \bmod 23=9$

$\mathrm{Z}(18)=(11 * 9+5) \bmod 23=12$

$Z(19)=(11 * 12+5) \bmod 23=22$

$Z(20)=(11 * 22+5) \bmod 23=17$

\section{E. Kerangka Konsep}

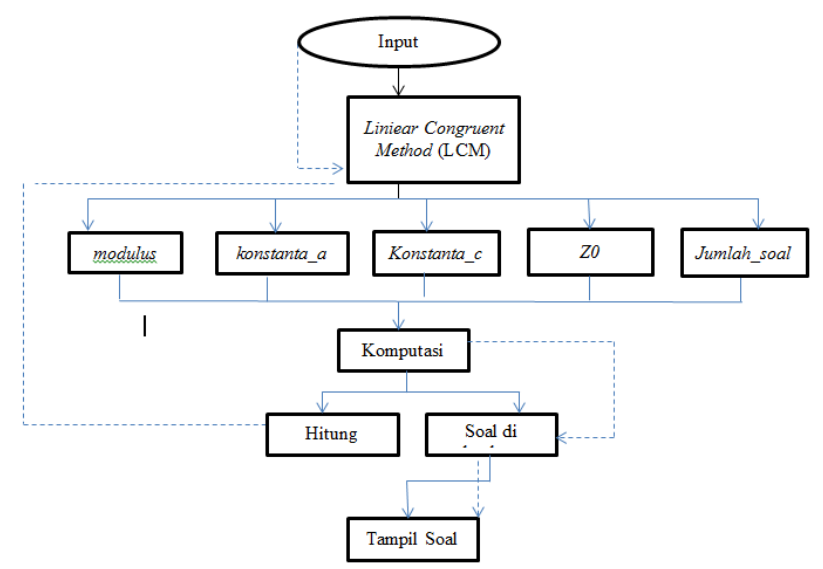

Gambar 10. Kerangka Konsep Penelitian

Penjelasan gambar kerangka konsep :
1.Pengacakan soal menggunakan metode Linear Congruent Method (LCM)

2.Inputan Metode LCM terdiri dari modulus, konstanta a, konstanta c, z0 yang harus di inputkan sesuai syarat - syarat metode $L C M$ untuk menentukan konstanta.

3.Pada komputasi akan menghitung sesuai inputan metode LCM yang telah dinputkan dengan otomatis menghasilkan angka acak sesuai perhitungan LCM dan akan mengambil soal pada database sesuai nomor yang dihasilkan oleh perhitungan.

4.Setelah itu maka akan tampil soal sesuai perhitungan yang telah diinputkan.

\section{HASIL DAN PEMBAHASAN}

Pada aplikasi ini di buat dengan bahasa pemrograman php. Adapun code program dari penggunaan linear congruent method dapat di lihat pada gambar 6 dibawah ini :

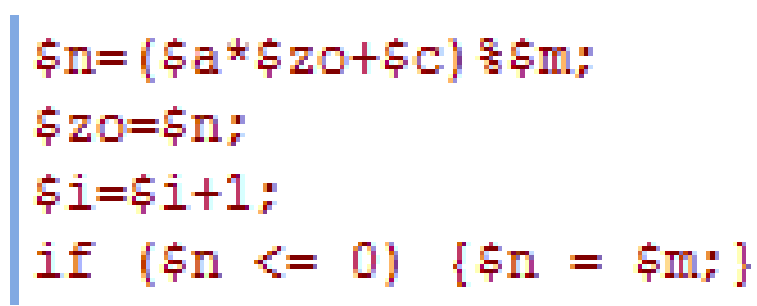

Gambar 11. Code Program Fungsi Acak Soal

A. Ujicoba

Dalam tahap ujicoba ini dilakukan dengan jumlah soal sebanyak 60 soal Pendidikan Kewarganegaraan Kelas V tanggal pelaksanaan ujian dan 5 paket soal. Adapun yang akan di inputkan sebagai berikut:

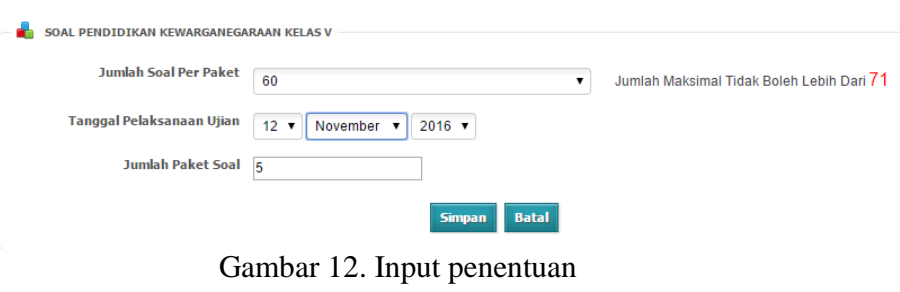

Berdasarkan ketentuan gambar diatas selanjutnya akan menampilkan menu form gambar di bawah ini :

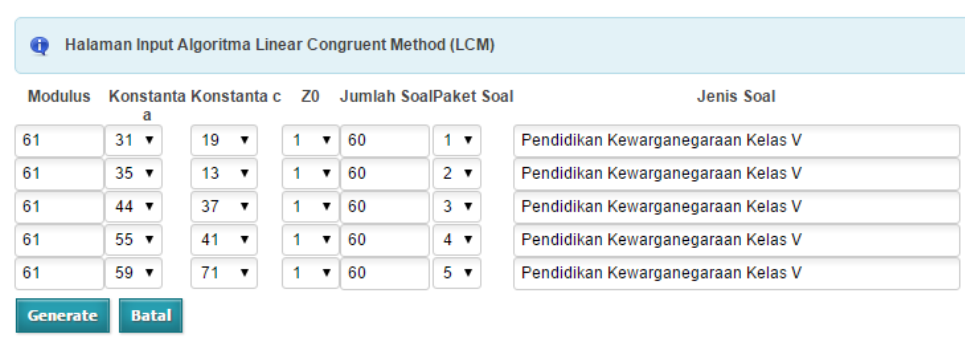

Gambar 13. Input Perhitungan LCM 
Gambar diatas sudah di tentukan input perhitungan lcm nya ada 60 soal dan 5 paket soal yang siap di generate.

Berikut adalah hasil genarate dari gambar 13 :

1. Paket Soal 1

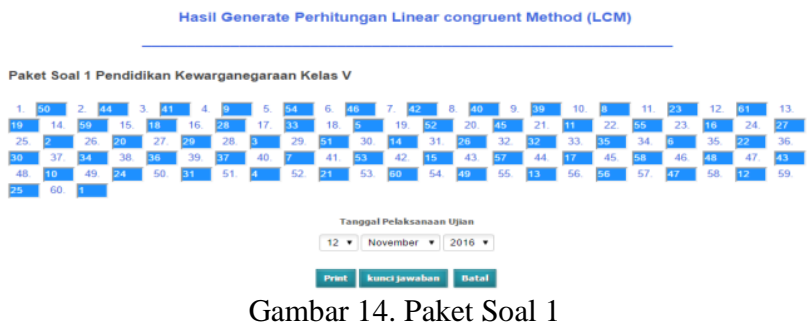

2. Paket Soal 2

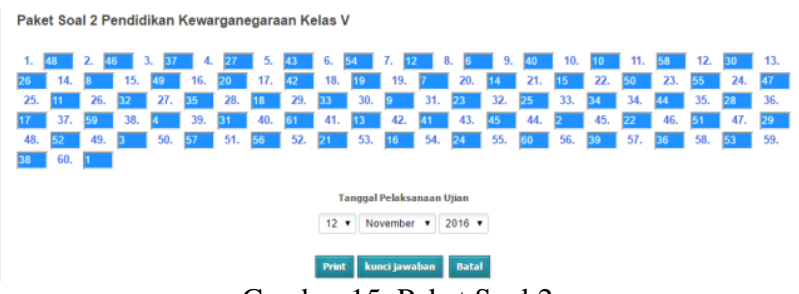

Gambar 15. Paket Soal 2

\section{Paket Soal 3}

Paket Soal 3 Pendidikan Kewarganegaraan Kelas $Y$

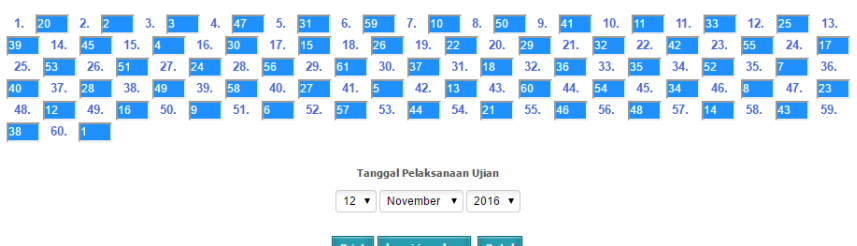

Gambar 16. Paket Soal 3

\section{Paket Soal 4}

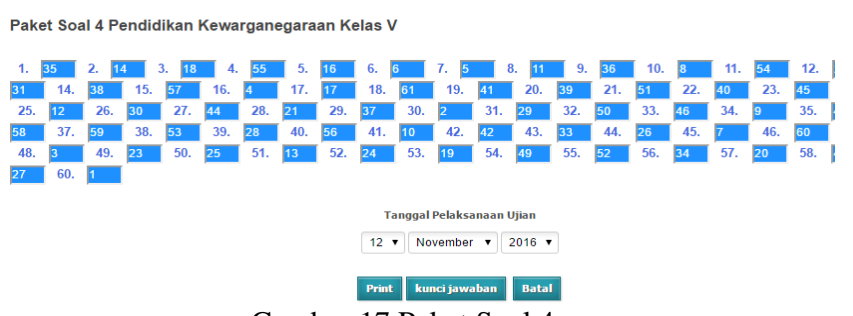

Gambar 17 Paket Soal 4

\section{Paket Soal 5}

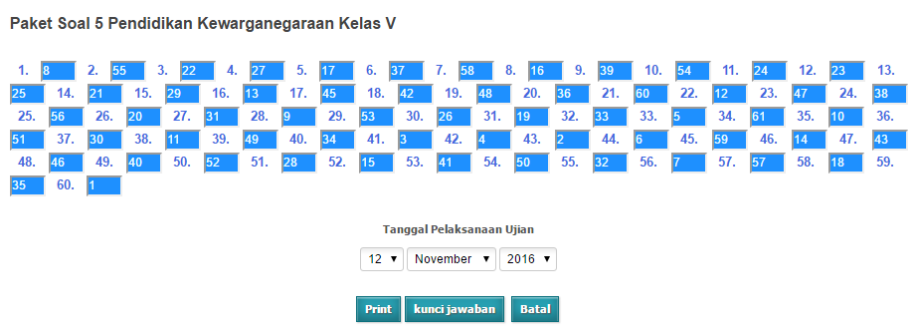

Gambar 18. Paket Soal 5

Tampilan soal saat di cetak akan seperti gambar dibawah ini :

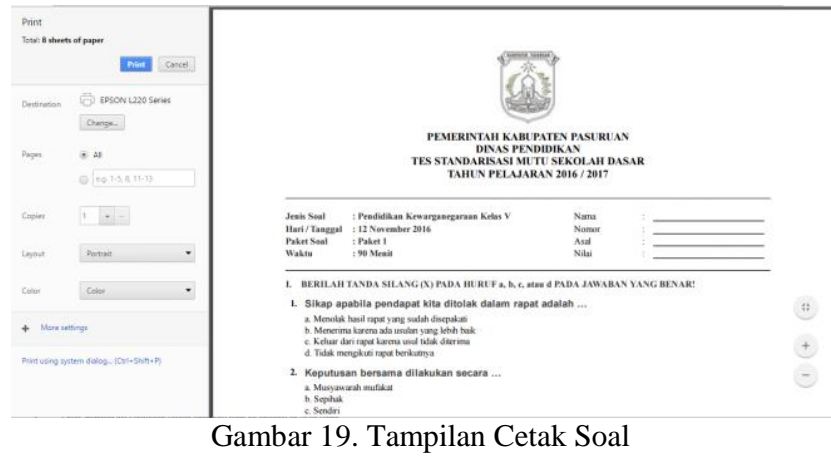

Dari gambar 19 menyatakan soal telah siap untuk dicetak sesuai dengan nomor soal yang ada di database dan pengambilan nomor soal sesuai dengan hasil generate yang telah di inputkan pada gambar 13. Pada gambar 19 bisa ditentukan ukuran kertas sesuai dengan kebutuhan.

Tampilan kunci jawaban saat di cetak akan seperti gambar dibawah ini :

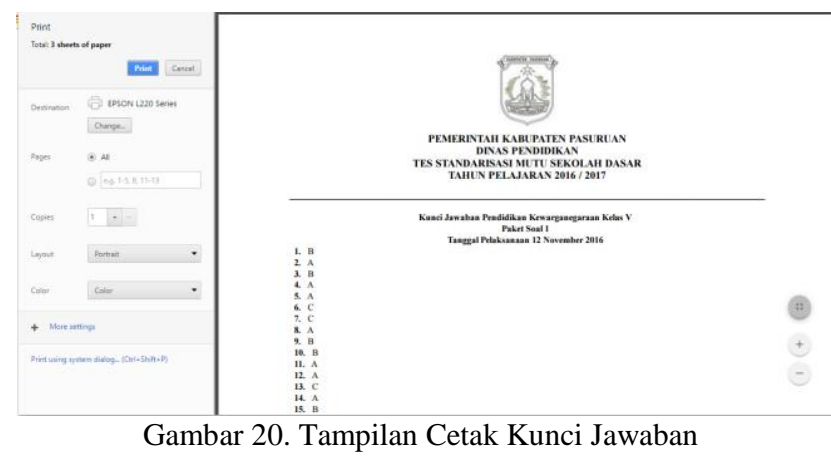

Dari gambar 15 menyatakan kunci jawaban telah siap untuk dicetak sesuai dengan nomor soal yang ada di database dan pengambilan nomor kunci jawaban sesuai dengan hasil generate yang telah di inputkan pada gambar 8. Pada gambar 15 bisa ditentukan ukuran kertas sesuai dengan kebutuhan. 
B. Anilisis Dan Pembahasan

Setelah dilakukan ujicoba penulis dapat mengetahui, pada saat input algoritma perhitungan metode Linear Congruent method (LCM) harus sesuai dengan persyaratan, jika salah maka angka akan berulang dan itu tidak seuai dengan soal pilihan ganda yang akan di tampilkan. Hakekatnya sebuah soal tidak boleh ada yang sama dalam 1 paket soal.

Jumlah maksimal penginputan soal sebanyak 151 soal dan jumlah minimal 30 soal. untuk paket soal tergantung kebutuhan yang akan disajikan pada saat ujian. perolehan angka pada saat proses pengacakan soal sama dengan perhitungan manual di microsoft excel.

\section{PENUTUP}

\section{A. Kesimpulan}

Sebagai penutup pembahasan pada jurnal ini, penulis mengambil kesimpulan-kesimpulan serta memberikan saran kepada pembaca maupun bagi yang ingin mengembangkan jurnal ini. Adapun kesimpulan sebagai berikut:

1. Cara yang digunakan dalam menyusun soal adalah dengan mengumpulkan soal-soal yang telah di buat oleh pembuat lalu di inputkan oleh user pada aplikasi ini supaya nanti dapat menjadi bank soal dan siap untuk di acak.

2. Dalam menerapkan linear congruent method (LCM) untuk pengacakan soal-soal, ada hal-hal yahng harus diperhatikan. Penggunaan konstanta a, c, dan $\mathrm{m}$ sangat menentukan pengacakan yang terjadi sehingga dengan kombinasi konstanta yang tepat maka akan dihasilkan pengacakan soal yang benar-benar acak.

Dalam merancang pengacakan soal, ada beberapa hal yang harus diperhatikan. Data dan metode yang dipakai dalam aplikasi. Adapun metode linear congruent method bekerja sebagai pengacak soal-soal sehingga setiap paket soal memiliki soal yang berbeda seperti paket ujian nasional yang ada.

B. Saran

Penulis ingin memberikan saran yang mungkin berguna untuk pengembangan lebih lanjut pada jurnal ini. Ada pun sarannya sebagai berikut :

1. Penentuan nilai konstanta LCM (a, c dan m) sangat mempengaruhi baik tidaknya pembangkitan bilangan acak. Sehingga hal ini menjadi sangat penting dan harus diperhatikan untuk mengahasilkan bilangan yang benarbenar acak.

2. Ada banyak metode pembangkitan bilangan acak yang dapat digunakan. Salah satu nya adalah metode Monte Carlo yang dapat digunakan untuk melakukan pengacakan dalam simulasi. Dengan mempelajari metode tersebut, diharapkan dapat mengatasi kelemahankelemahan pada metode LCM sehingga dapat lebih memperbaiki program yang terdapat dalam Jurnal ini.

3. Diharapkan bisa bermanfaat bagi semua kalangan karena aplikasi ini tidak hanya untuk sekolah melainkan untuk kalangan lainnya bisa juga di gunakan karena adanya form header yang bisa di rubah sehingga instansi atau perorangan bisa memakai aplikasi ini.

\section{Ucapan Terima Kasih}

Penulis menyampaikan ucapan terima kasih kepada dosen Pembina penelitian yang telah mencurahkan pikiran hingga selesainya penelitian ini. Serta ucapan terima kasih kepada Jointecs yang telah melakukan revisi hingga terbit artikel ilmiah ini.

Referensi

[1] Andriasnyah. (2014). Perancangan Aplikasi Game Edukasi Menggunakan Metode Linier Congruent Method (LCM).

[2] Aplikasi. (t.thn.). Dipetik April 28, 2016, dari Wikipedia: https://id.wikipedia.org/wiki/Aplikasi

[3] Astah. (t.thn.). Dipetik April 28, 2016, dari Wikipedia: https://en.wikipedia.org/wiki/Astah*

[4] Basis Data. (t.thn.). Dipetik Agustus 10, 2016, dari Wikipedia: https://id.wikipedia.org/wiki/Basis_data

[5] Budayasa, I. G., \& Paryatna, G. (2013). Implementasi Linear Congruential Generator dalam Rancang Bangun Aplikasi Game Peduli Lingkungan. Jurnal Nasional Pendidikan Teknik Informatika (JANAPATI).

[6] Diagram hubungan entitas. (t.thn.). Dipetik Agustus 10, 2016, dari Wikipedia: https://id.wikipedia.org/wiki/Diagram_hubungan_entitas

[7] Djunaidi, P. T. (2015). Implementasi Linier Congruent Method Untuk Pengacakan Soal Ujian Pada Aplikasi Belajar Hiragana.

[8] Hasibuan, D. P. (2013). PERANCANGAN SIMULASI PENGACAKAN SOAL TRYOUT UNTUK MEMBENTUK PAKET SOAL UJIAN NASIONAL MENGGUNAKAN LINEAR CONGRUENT METHOD (LCM).

[9] Hasyim, N., Hidayah, N. A., \& Latisuro, S. W. (2014). RANCANG BANGUN SISTEM INFORMASI KOPERASI BERBASIS WEB PADA KOPERASI WARGA BARU MTS N 17 JAKARTA.

[10] JavaScript. (t.thn.). Dipetik April 2016, 28, dari Wikipedia: https://id.wikipedia.org/wiki/JavaScript

[11] Kamus Data. (t.thn.). Dipetik Agustus 11, 2016, dari Wikipedia: https://id.wikipedia.org/wiki/Kamus_data

[12] Microsoft Sharepoint Designer. (t.thn.). Dipetik April 28, 2016, dari Wikipedia: https://id.wikipedia.org/wiki/ Microsoft_SharePoint_Designer

[13] MySQL. (t.thn.). Dipetik April 28, 2016, dari Wkipedia: https://id.wikipedia.org/wiki/MySQL

[14] PHP. (t.thn.). Dipetik Apri 28, 2016, dari Wikipedia: https://id.wikipedia.org/wiki/PHP

[15] Pratami, M., Satria, E., \& Cahyana, R. (t.thn.). PERANCANGAN SISTEM INFORMASI PEMBAYARAN DANA INSENTIF PEGAWAI DI STTGARUT.

[16] Sekarsari, D. (2014). Implementasi Metode LCM (LINEAR CONGRUENT METHOD) Pada Permainan Ludo.

[17] Sulistyorini, P. (2009). Pemodelan Visual dengan Menggunakan UML dan Rational Rose.

[18] Ujian. (t.thn.). Dipetik Agustus 11, 2016, dari Wikipedia: https://id.wikipedia.org/wiki/Ujian

[19] Xampp. (t.thn.). Dipetik Agustus 10, 2016, dari Wikipedia: https://id.wikipedia.org/wiki/XAMPP 